\title{
ARTICLE \\ Informal Exercise of Power: Undermining Democracy Under the EU's Radar in Hungary and Poland
}

\author{
Edit Zgut ${ }^{1}$
}

Accepted: 16 February 2022 / Published online: 2 March 2022

(c) T.M.C. Asser Press 2022

\begin{abstract}
Hungary and Poland have seen the most widespread erosion of democracy in the European Union since Fidesz and Law and Justice started their authoritarian remaking in 2010 and 2015, respectively. Despite the EU's introduction of various doctrinal innovations, it could not force these regimes to comply with the core values of the EU. While the literature has focused on the formal violation of the rule of law, the links between informal power and the limited constraining role of the EU have remained undertheorized. This article aims to fill the gap by studying the informal exercise power of the Fidesz and PiS governments that helped them to create an uneven political playing field. Connecting the literature on hybrid authoritarian regimes and informality, it will be shown through three main domains how the Hungarian and Polish governments (1) distributed informal political-economic decisionmaking power informally throughout clientelist corruption, (2) captured the media through loyal oligarchs/allies, and (3) employed electoral clientelism to tilt the electoral playing field in their favor. While the study proposes a theoretical framework related to the Hungarian and Polish examples, it is also a warning for the EU to take the informal exercise of power seriously.
\end{abstract}

\section{Introduction}

Over the past decade, the quality of democratic governance has fallen the most in Hungary and Poland of any member states in the European Union. ${ }^{1}$ A scholarly consensus have emerged that since Fidesz (Magyar Polgári Szövetség) came to power in Hungary in 2010 and Law and Justice (Prawo i Sprawiedliwość, PiS) won the elections in Poland in 2015, these two countries have undergone a significant systemic change. These regimes are among the prime examples that the process of democratic

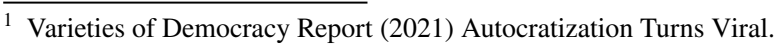

Edit Zgut

ezgut@ifspan.edu.pl

1 Institute of Philosophy and Sociology, Polish Academy of Sciences, Warsaw, Poland
} 
consolidation has not been a one-way trajectory in Europe after the fall of the Soviet Union. According to the global democracy indexes, Hungary has ceased to be a consolidated democracy (Varieties for Democracy $2020^{2}$ ) and became a hybrid authoritarian regime (Nations in Transit $2020^{3}$ ), while Poland is rapidly shifting towards the same direction.

Whereas every regime type is working through a combination of formal and informal practices, hybrid political regimes or regimes with considerable democracy deficits are in particular characterized by informal institutions. ${ }^{4}$ In order to capture the essence of democratic deterioration in Central and Eastern Europe, we need to go further beyond analyzing the formal institutions and extend the scope onto the informal side of politics. ${ }^{5}$

In order to alter the political system, Hungary has been using and abusing its Fundamental Law, while Poland has been disregarding its 1997 Constitution and, at the same time, creating its new invisible illiberal constitution. ${ }^{6}$ Thus, most studies significant of rule of law and democratic backsliding in these countries by Bozóki and Hegedús, ${ }^{7}$ Halmai $^{8}$ and Sadurski ${ }^{9}$ are centered on formal institutional changes that have undermined democracy, and they pay little attention to another crucial factor: informal exercise of power. The existing literature on democratic backsliding teaches us little about how informal exercise of power is used by these governments to tilt the playing field to consolidate control over the state and society in the European Union.

The aim of this article is to provide a more nuanced picture of the substance of democratic backsliding by analyzing various informal interactions of the Hungarian and the Polish government that are "created, communicated and enforced outside of officially sanctioned channels." 10 While most studies on the region's informal tendencies focuses on party politics ${ }^{11}$ and argues that informality prevails throughout

\footnotetext{
2 Varieties of Democracy Report (2021).

3 Nations in Transit (2021) Report.

${ }^{4}$ Christian G, Hayoz N (2013) Informality in Eastern Europe: structures, political cultures and social practices.".

5 Dimitrova AL (2010) The new member states of the EU in the aftermath of enlargement: do new European rules remain empty shells? J Eur Pub Pol 17:1, 137-148, https://doi.org/10.1080/135017609034649 29

6 Drinóczi T, Bień-Kacała A (2020) Rule of law, common values, and illiberal constitutionalism. Routledge.

7 Bozóki A, Hegedús D (2018) An externally constrained hybrid regime: Hungary in the European Union, Democratization 25:7, 1173-1189.

${ }^{8}$ Halmai G (2018) The possibility and desirability of rule of law conditionality. Hague J Rule Law 2018.

9 Sadurski W (2019) Polish constitutional breakdown. Oxford University Press.

${ }^{10}$ Helmke G, Levitsky S (2004) Informal institutions and comparative politics: a research agenda. Perspect Polit 2(4): 725-740.

11 See Grzymala-Busse A (2007) Rebuilding leviathan: party competition and state exploitation in postcommunist democracies (Cambridge Studies in Comparative Politics). Cambridge: Cambridge University Press. DOI https://doi.org/10.1017/CBO9780511618819 and Volintiru C (2016) Clientelism and Cartelization in Post-communist Europe: The Case of Romania.
} 
external economic actors' influence on the party system in a client-client context, ${ }^{12}$ this article employs a different approach. It integrates informality as one of the aspects of the exercise of governmental power into the analysis of the regime.

Paying greater attention to informal exercise of power is important because the EU procedures are monitoring the institutional and legal systems and are ill-suited to address informal mechanisms of the governments. While the EU is designed in a way that it can mostly address formal institutional changes through its rule of law instruments, ${ }^{13}$ regimes that operate via informal exercise of power tend to " fly beneath the radar' of the EU, thus evading its scrutiny.

Despite the fact that the EU institutions have developed a wide range of tools with which the rule of law and democratic deterioration can be addressed, including the Conditionality Mechanism, so far they have not managed to prevent democratic breakdown in Hungary or Poland. ${ }^{14}$ The example of these countries have proven that their constraining role is rather limited and there are various political and economic incentives that provide a safe environment for these regimes to operate in the EU. ${ }^{15}$

Both governments are "untouchable" for Brussels for two reasons. One of them is the lack of political will: as Kochenov and Bárd put it, the Council is the firmest of all the institutions in terms of downplaying the rule of law problem itself. ${ }^{16}$ Slow EU procedures, mainly dominated by the exchange of correspondence in the name of "dialogue" give further leeway and more time to such autocrats to change the system.

The second is that the EU procedures aimed at monitoring the institutional and legal systems do not address the informal exercise of power politics that is more difficult to identify than formal mechanisms of repression. Due to the institutional shortcomings, the EU's legal framework was ill-suited enough not to address formal abuse of power, let alone informal abuses. Instruments, like the the Rule of Law Mechanism are typically targeting specific violations of EU law and, they cannot grasp the accumulated effect of many small legislative changes, or Orbán's use of informal power to drive democratic backsliding. On top of that, slow EU procedures, mainly dominated by the exchange of correspondence in the name of "dialogue" give further leeway and more time to autocrats to change the system.

Whereas the literature focuses on the analysis of the EU's formal institutional and legal frameworks and ends up wondering how autocrats manage to evade them, this article posits three ways in which the Fidesz and PiS government develop and use informal exercise of power to achieve its authoritarian goals. It identifies how political-economic decision-making power is being distributed informally throughout

\footnotetext{
${ }^{12}$ Klíma M (2019) Informal politics Informal politics in post-communist Europe: political parties, clientelism and state capture. Routledge.

${ }^{13}$ Gora A, Wilde P (2020) The essence of democratic backsliding in the European Union: deliberation and rule of law. J Eur Pub Pol. https://doi.org/10.1080/13501763.2020.1855465

14 Halmai (2018).

15 Kelemen RD (2020) The European Union's authoritarian equilibrium. J Eur Pub Pol 27:3, 481499. https://doi.org/10.1080/13501763.2020.1712455q

${ }^{16}$ Kochenov D, Bárd P (2019) The Last Soldier Standing? Courts vs. Politicians and the Rule of Law Crisis in the New Member States of the EU. University of Groningen Faculty of Law Research Paper No. 5/2019.
} 
clientelist corruption centered around Hungarian Prime Minister Viktor Orbán and Deputy Prime Minister Jarosław Kaczyński. Secondly, it describes how the ruling parties can wield power informally through media capture to silence critical outlets. Thirdly, it explores systematic clientelism through the electoral process to explore how Fidesz and PiS used informal tools of influence to help tilt the electoral playing field in their favor. I will test through these domains how informal power prevails on a multiple level, bending both economic allies and the broader electorate to the regimes' will.

The empirical research was based on desktop research and 50 qualitative semistructured expert interviews in both countries. Besides using primary and secondary sources such as reports of international and national NGOs, watchdog organizations, and the currently existing literature, the interviews were the backbone of the sources of information. While focusing on the aforementioned three main domains, the article studies academic experts, think-tankers, journalists, and representatives of civil society organizations who are focusing on democracy and rule of law issues in both countries. The analysis is confined to the period between 2010 and 2021 September when both governments have undergone significant systemic changes that resulted in launching Article 7 of the TEU. (In case of Hungary, between 2010 and 2021, in case of Poland between 2015 up until 2021.)

The article is structured as follows: first, a conceptual summary is provided on the notion of informal exercise of power in hybrid authoritarian context. Then the case selection and methods are asserted, which is followed by the empirical analysis via three main domains. The study is concluded with comparative lessons. Besides connecting the literature on hybrid authoritarian regimes and informal exercise of power via three main themes, and proposing a theoretical framework related to the Hungarian and Polish example, this study is also a warning for the EU to take the informal exercise of power seriously.

\section{Triggers of Informality in CEE}

Whereas informality in general has been discussed within the theoretical framework of authoritarianism, informal exercise of power in CEE remained relatively underdiscussed in the context of hybrid authoritarian regimes. The emphasis on formal institutions has been very much in evidence in the literature on democratic backsliding-both in general and in the EU context specifically. ${ }^{17}$ By contrast, this article develops a theoretical framework that highlights the central role that the exercise of informal exercise of power and informal institutions play in democratic backsliding and in the operation of hybrid regimes. Drawing upon the explicit definition of by Helmke and Levitsky, ${ }^{18}$ I refer to informality in terms of institutions that have "socially shared rules, usually unwritten [...], created, communicated and enforced outside of officially sanctioned channels."

\footnotetext{
17 Gora A, Wilde P (2020).

18 Helmke G, Levitsky S (2004) Informal institutions and comparative politics: a research agenda. Perspect Polit 2(4): 725-740.
} 
Given the focus of the article, it is worth looking into the triggers of informality in CEE to better outline the potential contours of informal exercise of power in Hungary and Poland. While informal characteristics of politics is not exclusively negative, robust research ${ }^{19}$ has shown that undemocratic, illegitimate, often mutually reinforcing informal practices undermine democracy in this region. In the words of Klíma, ${ }^{20}$ the post-1989 development was structurally embedded in the environment of both the communist legacy and the post-communist transition. Structural factors such as lack of division of power, extraordinary interconnection of the public and private spheres and the absence of a strong civil society and middle class were all accelerating pro-clientelist conditions.

Despite the common assumption of the democratization literature on how EU integration has had a beneficial effect on democratic consolidation, ${ }^{21}$ the accession procedure has also encouraged non-democratic forms of informality through its conditionality policy. As Slapin ${ }^{22}$ argues convincingly, the reforms required of candidates could have "the perverse effect of undermining the establishment of legitimate law in transitional democracies".

While the Copenhagen conditions were supposed to ensure that new member states would not undermine the democratic and/or economic fabric of the EU, Pridham $^{23}$ emphasizes the prevalence of a 'box ticking' mentality that was employed in a very top-down and deadline-dominated fashion. Considerable research ${ }^{24}$ pointed out that while drastic reforms as a condition of membership were accepted on a large scale, national governments failed to actively enforce them. As a result, reforms that were instituted to satisfy EU box-ticking exercise neither led to substantive changes in practices nor proved sustainable in some cases after the goal of accession had been achieved. The Western Balkans is another profound example that the EU conditionality has not only triggered positive developments, but the accession conditionality has entrenched informal networks and enabled them to strengthen their grip on power. ${ }^{25}$

\footnotetext{
19 Meyer (Hg.) (2008) Formal institutions and informal politics in Central and Eastern Europe. Hungary, Poland, Russia and Ukraine.

20 Klíma M (2019).

21 Vachudova MA (2005) Europe Undivided: democracy, leverage, and integration after communism, OUP Catalogue, Oxford University Press, number 9780199241194.

22 Slapin JB (2015) How European Union Membership Can Undermine the Rule of Law in Emerging Democracies, West European Politics, 38:3, 627-648, https://doi.org/10.1080/01402382.2014.996378

23 Pridham G (2009) Securing the Only Game in Town: The ELPs Political Conditionality and Democratic Consolidation in Post-Soviet Latvia. EUROPE-ASIA STUDIES S3 Routledge Taylor \& Francis Group Vol. 61, No. 1, 51-8.

${ }^{24}$ Guasti P, Dobovšek B (2011) "Informal institutions and EU accession: corruption and clientelism in central and eastern Europe 12.”.

25 Richter S, Wunsch N (2019). Money, power, glory: the linkages between EU conditionality and state capture in the Western Balkans. J Eur Pub Policy.
} 


\section{Informal Exercise of Power}

Consequently, informal interpretations of formal institutions dominated post-communist countries. One of its manifestations is political clientelism, a multidimensional phenomenon that applies to all types of political regimes. As a method of electoral mobilization, it has been traditionally defined as "the proffering of material goods in return for electoral support". ${ }^{26}$ It is the distributive criterion of electoral support that distinguishes clientelism from other materially oriented political strategies, such as pork-barrel politics. It can also serve the goal of organizational mobilization to maintain power. ${ }^{27}$ While list of services and goods are unlimited, it could be classified both as interpersonal relationship and party-directed patronage, ${ }^{28}$ as personalistic awarding of jobs, contracts, and public policies that favor private allies without constitutional responsibility would also fall into this category. Patronage would represent how political parties seek to instrumentalize public institutions and resources to their benefit and how favors are exchanged for electoral support.

The two interrelated key factors about political clientelism are that while it is conditional, it is strongly based on an asymmetric personal relationship from which the most deprived clients could hardly withdraw. In other words, the person who receives the offer cannot benefit but can only choose between losing a greater amount by rejecting it, or losing a smaller amount by accepting the offer. ${ }^{29}$

Clientelism also carries a high risk of corruption. Sajo ${ }^{30}$ has discussed the two concepts under one roof by claiming that corruption has become the foundation of the Post-Communist region's clientelist social structure. He conceptualized this state-centered phenomena as "clientelist corruption," as a "form of structural corruption" which should be distinguished from the discrete individual acts of corruption.

A practical advantage of establishing a clientelist system is that it helps structuring intra-elite competition. It allows the patron to pit individual members of the political elite against one another to secure his/her position as the sole arbiter of the elite. Therefore, informality "fits the patrimonial logic of the ruler", who has the hierarchical machine on his side as well as the state's formal ideology and legal power. $^{31}$

When it comes to the informal linkage between economic and political power, part of the Post-communist region could be best characterized by the "informal

\footnotetext{
${ }^{26}$ In Goodin RE (2009) The Oxford handbook of political science.

27 Piattoni S (2001) Clientelism, interests, and democratic representation : the European experience in historical and comparative perspective.

28 Graziano L (2006) Patron-client relationships in southern Italy. Eur J Polit Res 1: 3-34. https://doi. org/10.1111/j.1475-6765.1973.tb01281.x.

29 Magyar B, Madlovics B (2020) The anatomy of post-communist regimes-a conceptual framework. Central European University Press.

30 Sajó A (2003) From corruption to extortion: conceptualization of post-communist corruption. Crime Law Social Change 40:171-194.

31 Koehler K (2008) Authoritarian elections in Egypt: formal institutions and informal mechanisms of rule. Democratization, 15:5, 974-990, https://doi.org/10.1080/13510340802362612
} 
collusion of power and ownership". Magyar and Madlovics ${ }^{32}$ classified it as a societal structure because property relations define the connection between people down to the everyday life of ordinary subjects of a feudal state. In hybrid authoritarian regimes, a clientelistic network of media ownership has a significant role, where control over the autonomous broadcasting regulatory agency by government appointees enables the acquisition of private media outlets and licenses (frequencies) and facilitates bias in broadcasting which is being tolerated by loyalist authorities. ${ }^{33}$ These cronies use the revenue generated in their government supported businesses for the acquisition and operation of media outlets.

Extensive theoretical and empirical studies ${ }^{34}$ have shown that concentrated political power is used to maintain the clientelistic system where "in exchange of the goodies the beneficiaries perpetuate the power of their patrons". If power is a relationship in which an actor has the capacity to get another actor to do what they do not want to do ${ }^{35}$ and formal power is officially vested and wielded by official authorities in institutions through codified means, informal exercise of power wielded unofficially - it is uncodified and not legally sanctioned.

Based on the aforementioned and the call to investigate how informality is used in hybrid authoritarian regimes, informal exercise of power refers to the uncodified, informally enforced interactions of the government that create an uneven playing field to its benefit. It takes both organizational and electoral clientelist exchange which creates a system of dependence not only between the political/economic/civic actors closely allied with the regime, but also between the voters and the government. Informal exercise of power is often being used by the government in a coercive way to consolidate control over the state and the society. These informal means of coercion are more difficult for international observers to identify than formal mechanisms of repression. ${ }^{36}$

\section{Informal Distribution of Decision-Making Via Clientelist Corruption}

\subsection{Orbán-Centered Political State Capture}

Having a landslide victory in 2010, Fidesz changed the Constitution, including the electoral law multiple times by fostering the idea of the so-called "Central field of power". It was originally defined by Orbán in 2009 as a departure from a competitive democratic model to monopolistic party system to put an end to the dualistic party elite which defined the Hungarian political landscape after 1989. In his view, Hungarian politics can be characterized by one dominant governing party "capable

\footnotetext{
32 Magyar and Madlovics 2020.

33 Sajo A, Juha T (2018) The rule of law and legitimacy in emerging illiberal democracies. Osteuropa Recht 64: 506-529. https://doi.org/10.5771/0030-6444-2018-4-506.

34 See Sajó 2017; Koehler 2008; Giordano and Hayoz 2013.

35 Dahl RA (1957) The concept of power. Behav Sci 2:201-215.

${ }^{36}$ Levitsky S, Way L (2010) Competitive authoritarianism: hybrid regimes after the cold war. Cambridge University Press.
} 
of articulating a national agenda" with a fragmented opposition that is not able to challenge the ruling party.

Although informality defines this system as a whole, the Orbán regime has put a great emphasis on what Scheppele called 'authoritarian legalism'. ${ }^{37}$ She argued that new autocrats of the European Union are undermining constitutionalism while claiming the legitimacy of a democratic mandate to rewrite the constitutional rules. While decisions are often formally taken in accordance with national legislation, the Hungarian government is instrumentalising the law to fit the authoritarian goals of the regime in an informal way. As an interviewee put it: "Legal scholars struggle to conceptualise the erosion of the rule law, as it does not imply formal legal changes but the gradual loss and distortion of the normativity of the legal system. For instance, even though Hungary has a decent Criminal Code, prosecutors and policemen apply the law in a politically biased manner: while they do not prosecute cases related to the government and to the family of the Prime Minister, they are very active and agile when it comes to cases related to the opposition." 38

Political power is concentrated in the hands of Orbán, which has been characterized by Kornai ${ }^{39}$ as "central-vertical coordination based on a hierarchical command system". Decision-making often prevails outside the formal institutional framework with the involvement of actors without constitutional responsibility, including the close relatives of the Prime Minister. The regime is relativizing and undermining the weight of the formal institutions: for instance, the Minister of Economy, Mihály Varga serves the role of a transmission-belt, lacking any meaningful political autonomy in the system. ${ }^{40}$ At the same time, one of the main advisors of Orbán, Árpád Habony has the power equivalent of a minister without having any formal position in the government. There was a consensus among my interviewees that although there are always 2-3 people that influence Viktor Orbán, it's always the Prime Minister who ultimately makes the final decisions.

As one of my interviewees has claimed: "A very small bunch of people are making decisions informally that are being distributed through formalised channels that fits the legislative procedure. But even formal decisions are made in a non-transparent way that they are not well documented. The withdrawal from the practise of having minutes and sound recordings of government meetings is a profound example of it." 41

The main goal of the government was to reshape the ownership of firms in key domestically orientated sectors in favor of Hungarian owners. ${ }^{42}$ The regime has been building up an exclusionary business-state-party alliance that allows access to public

\footnotetext{
37 Scheppele KL (2018) Autocratic legalism.

38 Interview with Andras Jakab, Professor of Constitutional Law at the University of Salzburg, May 12, 2020, Warsaw.

39 Kornai J (2017). Látlelet—Tanulmányok a magyar állapotokról, HVG Könyvek.

40 Interview with Andras Bozoki, professor at CEU, November 10, 2020 Budapest.

41 Interview with Andras Léderer, Director of K-Monitor, May 10, 2020 Warsaw.

42 Sallai D, Schnyder G (2021) What is "authoritarian" about authoritarian capitalism? the dual erosion of the private-public divide in state-dominated business systems. Bus Soc 60(6):1312-1348.
} 
procurement-including EU-funded projects- for a very limited number of actors. ${ }^{43}$ Tailor-made economic legislation with the involvement of the allies of the Prime Minister became prominent. The issue of the Tobacconist's shops concession demonstrated how the government created state monopolies for its own goals. Not only has it been redistributed among the most loyal members of Fidesz, but the legislative act was written on the computer of Continental's CEO, a close friend of Viktor Orbán. ${ }^{44}$

According to the Corruption Research Center Budapest, the corruption risk in public procurement grew considerably after the change of government in 2010 and in 2020 it reached its highest level since $2005 .{ }^{45}$ My interviewee argued that the system is clearly dominated by political favoritism: "Between 2011 and 2020, companies owned by entrepreneurs centered around the government gained significant advantage in the competition for public procurement contracts." 46

Various "economic centers" have arisen under the names of Lőrinc Mészáros, a childhood friend of the Prime Minister; György Matolcsy, the governor of the Hungarian National Bank; István Tiborcz, the son-in-law of the Prime Minister, István Garancsi, a construction entrepreneur and a personal friend of Orbán; Antal Rogán, Head of Cabinet of the Prime Minister; and János Lázár former chief of staff of the PM based upon their personal loyalty to Viktor Orbán. The common denominator of their businesses-besides rent-seeking-is that they are competitive on a domestic level only. Empirical research ${ }^{47}$ have shown that companies centered around the government "typically win in segments of the public procurement market characterized by higher corruption risk, lower control of corruption, and lower intensity of competition". Formally, most of them are independent business actors who eventually became an integral part of the patron's informal network, where decisions are not made within the formal bodies of the government.

With the help of these allies, the regime has successfully captured the most important sectors of the economy by 2021. One of the key figures in Hungary's crony clientelist system that revolves around the prime minister is Lórinc Mészáros, who became the country's wealthiest person in just a few years after Fidesz came to power. The speed at which he accumulated wealth is indicative of the system's informality: Mészáros's companies have won an unprecedented number of public contracts since 2010, 83 percent of which have been financed by EU-funded public procurement projects. ${ }^{48}$ In 2017, he lost a court case before the Budapest-Capital

\footnotetext{
43 Interview with László Bruszt, co-director of the CEU Democracy Institute and professor of sociology at the Central European University, November 7, 2020, Budapest.

44 Sallai D, Schnyder G (2020) What is "authoritarian" about authoritarian capitalism? The dual erosion of the private- public divide in state- dominated business systems.

45 Corruption Research Center Budapest (2020) New Trends in Corruption Risk and Intensity of Competition in the Hungarian Public Procurement from January 2005 to April 2020.

46 Interview with János István Tóth, director of the Corruption Research Center Budapest, October 28, 2020, Budapest.

47 Tóth JI, Hajdu M (2021) Cronyism during the Orbán Regime An empirical analysis of public tenders 2005-2020_under publication.

48 Erdélyi K (2018) “Túlnyomó részt uniós forrásokból gazdagodtak Mészáros Lôrinc családi cégei az elmúlt hét évben,” Átlátszó, January 15, 2018.
} 
Regional Court of Appeals against the opposition party Együtt, which had claimed that he only nominally owned his wealth and was a proxy of the prime minister. ${ }^{49}$

The prime minister's family members are among the biggest beneficiaries of this system. ${ }^{50}$ For example, István Tiborcz was involved in the fraudulent use of $€ 40$ million from EU funds between 2011 and 2015. ${ }^{51}$ His company group also reportedly received billions of forints from a Central Bank scheme for smaller businesses affected by the coronavirus pandemic, despite being listed by Hungarian Forbes as the 60th most-valuable Hungarian-owned company. ${ }^{52}$

In addition, investigative journalists revealed in 2020 that the mining company of Orbán's father, Dolomit Kft., offers its products at a significantly higher pricesometimes 60 to 70 percent higher-than its main competitors when it is a supplier for state investment projects. ${ }^{53}$ While Orbán's closest family have remained subcontractors in public procurement over the last 10 years, at the end of last year Gamma Amalcont, of which his younger brother is a minority owner, won a HUF 268 million public-procurement contract to provide remote monitoring service of gas networks worth. ${ }^{54}$

Whereas the constitution states that "Property may be expropriated only exceptionally and in the public interest, in cases and in the manner prescribed by law, with full, unconditional and immediate compensation," enterprise takeovers also became more frequent. One case indicative of the regime was the economic empire of Lajos Simicska, a former ally of Orbán, which was worth approximately HUF 60-80 billion, and ended up in the hands of Mészáros in 2019. Blurring the boundaries between the state and private sphere is the key in this matter. ${ }^{55}$

Pressure on different scales have been reportedly put on economic stakeholders independent of the government. One of the most notorious examples is Laszlo Bige, a Hungarian fertiliser magnate and the 10th wealthiest person who claimed to have been threatened by state authorities to sell out his business to oligarchs close to the Prime Minister.

\footnotetext{
49 Tamás Németh, "Mészáros másodfokon is vesztett a strómanos perben,” Index, March 27, 2017.

50 Interview with Bálint Magyar, research fellow at CEU's Democracy Institute, November 6, 2020, Budapest.

51 Racz T (2018) "EU Investigation Shows How Hungary Rigged Public Tenders," Organized Crime and Corruption Reporting Project, 2018.

52 Szabó A (2021) “Orbán's son-in-law and his associates among beneficiaries of favorable state covid loans," Direkt36, April 14, 2021.

53 Zöldi B (2020) "Orbán's father offers building materials for a much higher price than the competition,” Direkt36, December 16, 2020.

54 Szőke D (2021) “Until now, Orbán's family stayed away from public procurements. Now the company of his brother won a lucrative one," Direkt36, 2021.

55 Interview with József Péter Martin, director of Transparency International Hungary, October 29, 2020, Budapest.
} 


\subsection{Nepotism and Political Clientelism Around PiS}

Jarosław Kaczyński has always believed that the real power and efficiency of the state depends predominantly on personal and informal relationships ${ }^{56}$ Accordingly, since PiS came to power for the second time in 2015, Poland has become a textbook case of informal distribution of decision-making and executive power. The formal organizations and procedures of the state often do not determine how political decisions are made; instead, real decision-making authority is wielded through the informal practices of Kaczyński.

As one interviewee has framed it: "Regardless of his current formal position as a deputy prime minister, Kazynski has been serving a role similar to the first secretary of the Communist Party. As "the central organ of the state" that is not necessarily part of the formal structure of the government, he has an impact on the executive, the decision making and the judicial power too." ${ }^{, 57}$ In addition to that, Polish domestic politics has been dominated since 2015 by a power struggle between competing factions in the United Right alliance between PiS and its smaller allies, United Poland and Agreement. Kaczynski joined the government in November 2020 in order to keep in check the minister of justice and chief prosecutor, United Poland leader Zbigniew Ziobro, and to manage conflicts within the alliance. ${ }^{58}$

He became deputy prime minister and the chairman of the Committee of the Council of Ministers for National Security and Defense Affairs, a position that did not previously exist. ${ }^{59}$ His main task is the coordination of decision-making in these areas and to submit proposals to the Council of Ministers or the prime minister. This allows him to wield considerable informal power, despite the fact that he is no longer being a backbencher. ${ }^{60} \mathrm{He}$ independently makes important decisions, and the members of the government are strongly dependent upon their relationships with him. Policymaking under the PiS government is still guided by the leader of "Nowogrodzka" (the symbolic name of the street in Warsaw where PiS headquarter is based).

Although systemic political corruption is not a key feature of his regime, a 2019 scandal shed light on the concentration of political, business, and family ties around the PiS leader. According to the leaked Sreberna-tapes, while political parties are forbidden from conducting business activity, Kaczyński had personally coordinated a large-scale investment in Warsaw. ${ }^{61}$ Although the awareness of corruption

\footnotetext{
56 Research interview, December 19, 2020, Warsaw.

57 Interview with Adam Bodnar, Dean of the Faculty of Law at SWPS University and the formal Ombudsperson of Poland, November 9, 2020. Budapest.

58 Shotter J (2020) "What's at stake as Kaczynski returns to Poland's front line". Financial Times. September 30, 2020.

59 Dziennik Urzedowy Rzeczypospolitej Polskiej, Report, 2020.

60 Interview with Grzegorz Makowski, assistant professor at the Warsaw School of Economics, November 23, 2020, Budapest.

61 Hodun M (2019) "Two towers and Kaczynski tapes," 4Liberty, 2019.
} 
increased after the above mentioned tapes, he is not seen as being motivated by accumulating wealth but rather by power and control. ${ }^{62}$

In order to maintain power, the clientelistic exchange is centered around the distribution of state-political and state-commercial positions within the ruling party to cement loyalty to it and its power. Poland also avoided oligarchization, but PiS has become a quasi-oligarchical network linking political and corporate power, and an important dimension of its new economic policy was the so-called corporate governance (Jasiecki 2019).

After the government changed the corporate governance rules, which adversely affected the entire economy including the private sector, a large-scale turnover has taken place in the public sector and state-owned enterprises under the guise of PiS's policy of "decommunization." There has been a "huge increase in the politicization of the public sector, weakening the role of marital critics and market criteria in the decision of economic actors". 63 The government has used this process to distribute a large number of jobs to loyalists, many without professional experience, by lowering the requirements to fill certain posts. While this was an approach also taken by previous governments, it shifted into a new gear under PiS. An increasing number of close relatives and friends have taken high-level positions in these companies since 2015, regardless of their competences, in an untransparent way. ${ }^{64}$

According to investigative reporters, at least 900 people from the PiS community-family members, friends and colleagues-found employment in state-owned companies, including, among others KGHM, PKN Orlen and Azoty. This figure only includes data that is publicly available in company registers, so the actual level of nepotism could be even higher. Based upon the dataset provided by a joint investigation of Gazeta Wyborcza, Onet.pl and RadiZet, the majority of these employees are linked to Prime Minister Mateusz Morawiecki. Whereas he was picked by Kaczynski in 2016 to replace Beata Szydlo as Prime Minister as a politician who is not embedded into PiS party structures, he managed to extend his political power via state-owned companies and institutions supporting business development. Today, his main spheres of influence are the Polish Development Fund Group, PKO BP bank, PKN Orlen and Lotus, among others. ${ }^{65}$

Besides Morawiecki, other members of the United Right coalition are part of this nepotistic network such as Marius Blaszczak, Minister of National Defence of Poland, Joachim Brudzinski, an MEP of PiS, Zbigniev Ziobro, Minister of Justice and Jacek Sasin, Minister of State Assets. It resulted in two parallel trends: while

\footnotetext{
62 Interview with Stanley Bill, senior lecturer in Polish studies at Cambridge University, October 26, 2020, Budapest.

63 Jasiecki K (2019) Conservative modernization" and the rise of Law and Justice in Poland in: New Conservatives in Russia and East Central Europe (ed. Katharina Bluhm, Mihai Varga).

64 Dąbrowska A (2021) "Rodzina PiS na swoim - czyli dojenie państwowych spółek," Polityka, March $31,2021$.

65 Mikołajewska B (2021) Ludzie Morawieckiego. Przyjaciele z Solidarności Walczącej na państwowym [UJAWNIAMY PŁACE] September 28, 2021.
} 
the importance of meritocracy is declining, the influence of business interest groups that take advantage of companies for the benefit of the political elites is increasing. ${ }^{66}$

This clientelist exchange also contributes to helping maintain the parliamentary majority of PiS in 2021. Due to the long-standing conflicts then split with Gowin's Agreement party, PiS provided incentives to MPs to join the governing party in the Sejm. Financial incentives range from well-paying parliamentary positions to senior management positions in state-owned companies. Representative Lech Kołakowski, for example, returned to PiS by being offered a monthly salary of PLN 35,000 (more than HUF 3 million) at Bank Gospodarstwa Krajowego. Małgorzata Janowska, who left PiS in June 202 also rejoined the ruling party after her partner, Andrzej Legeżyński was appointed as head of a company in the predominantly state-owned Polish Energy Group (PGE). ${ }^{67}$

Whereas Poland avoided oligarchization and monopolized corruption to the scale of Hungary, the clientelistic system created by PiS showcased coercive traits too. Since the pandemic crisis started, PiS used appointments to different positions not only as a source of incentive but also of coercion. Political allies and opponents have also been pressured by clientelism. This was reflected during the parliamentary vote on animal rights in autumn 2020. Jan Maria Jackowski, a PiS senator, revealed that one of his colleagues was explicitly threatening that if he did not vote in accordance with Kaczynski, his family members would lose their jobs. ${ }^{6}$

Leaked tape recordings have shed further light on the coercive tactics of PiS, revealing how a "dissident" party member was threatened with losing his job unless he withdrew a petition that would have challenged the deputy mayor of the city of Wałbrzych. ${ }^{69}$

After the outbreak of the coronavirus pandemic, the government also selectively distributed ten times more EU funds to PiS-controlled local governments than to other ones. ${ }^{70}$ Although economic resources cannot be reallocated in a fully personalized way like in Hungary, the Polish procurement system is also exposed to irregularities. Poland has the highest rate of the so-called single-applicant tenders in the EU: only one entity submits an application to $46 \%$ of tenders. OLAF estimated that 19-23\% of Polish public procurements might be vulnerable to corruption.

\footnotetext{
66 Jasiecki (2019).

67 Stankiewicz A (2021) "Wysokie stawki prezesa PiS. Tak Kaczyński kupuje posłów”. Onet.pl August 12. 2021.

68 Dziubka K (2020) "Brutalne metody w PiS? Oskarżenia o zastraszanie i groźby wyrzucenia z klubu." Onet.pl. October 16. 2020. Available at: https://wiadomosci.onet.pl/tylko-w-onecie/piatka-dla-zwierzatbrutalne-metody-w-pis-oskarzenia-o-zastraszanie/jxr1nzk.

69 Onet (2021) "Nie prowokuj, bo cię zniszczą". Nagrano rozmowę dolnośląskich działaczy PiS," January $12,2021$.

70 Katka K (2021) "A committee packed with PiS loyalists distributed PLN 6 billion in aid for local governments along party lines", Gazeta Wyborcza, February 23, 2021. 1.
} 


\section{Informal Capture of the Media}

\subsection{Informal Media Market Distortion in Hungary}

Another means of consolidating power and creating an uneven playing field is the informal capture of the media. While media businesses linked to governing parties enjoyed strong market positions well before Fidesz was reelected in $2010,{ }^{71}$ the Orbán government was using powerful individuals and companies in an unprecedented way to silence critical media outlets. It created a top-down centralized system that was built upon a clientelistic network of media ownership. In 2020 Hungary fell to the 89th position, its lowest ever, in the World Press Freedom Index. ${ }^{72}$

Besides Mészáros, the pro-government media portfolio is currently dominated by Árpád Habony, the prime minister's advisor; Ádám Matolcsy, the son of the president of the Hungarian National Bank, György Matolcsy; Mária Schmidt, director of the House of Terror and a close associate of Viktor Orbán and István Garancsi. ${ }^{73}$ Our interviewed experts agreed that there is no direct pressure on these editorials and the journalists are also not being threatened physically. Instead, Hungary qualifies a classic state capture where journalists can not hold those in power to account due to conflicts of interests with the owners of media groups.

Under the new ownerships, they dismissed entire editorials and replaced the management with loyalists on the local level, who were willing to transform the outlet into non-critical mouthpieces. One of the pilot projects was in Székesfehérvár, where the Daily Newspaper of Fejér County was overtaken by Mészáros's Optimus. Professional trade unions were emptied out and local non-professional citizens were employed to provide new content. ${ }^{74}$ Lacking literate people, the editorial produced mainly local tabloid content with a massive amount of character assasinaton of the domestic opposition. ${ }^{75}$

In the spirit of top-down centralization, they also created so-called Municipal Communication Centers, led by Fidesz appointees which started to function as local news agencies. As a result, local newspapers now parrot exactly the same central messages published by the national pro-government media which of course contributed a lot to the electoral victory of Fidesz. The Media Centrums are dominating the local content and in case a young local journalist would seek a job in a municipality, there are not many ways but the above mentioned ecosystem. These local media platforms have impact and outreach by echoing the government's central propaganda while keeping quiet about local problems, government related corruption issues and sideline critical opinions.

\footnotetext{
71 Polyák G (2016) "The Hungarian Media System. Stopping Short or Re-Transformation? Directions and Achievements of the Media System Transformation".

72 Reporters without borders, 2020 World Press Freedom Index, 2020.

73 Bátorfy A and Urbán Á (2019). "State advertising as an instrument of transformation of the media market in Hungary,” East European Politics.

74 Interview with the Ernő Klecska, former editor of Fejér County Newspaper, October 27, 2020, Budapest.

75 Interview with Klecska.
} 
But the key to informal centralization was the creation of the Central European Press and Media Foundation (KESMA) under the supervision of Orbán's. Despite that it made no sense from the business point of view, 470 pro-government outlets "voluntarily" donated their highly valuable assets to a newly formulated, centralized foundation in 2018. The establishment of KESMA demonstrated that Hungary became a very classic example of informal media capture as these cronies have never been true owners of these media outlets. As a former media worker of this conglomerate put it: "Journalists in this empire would never risk reporting any information that would shed negative light on the government, let alone systemic corruption issues related to the Prime Minister's family. The main editorial rule is simple: praising the government and undermining the opposition by all means." 76 Furthermore, one of my interviewees argued that Orbán's role is essential when it comes to the dynamic changes in the media market. "There is no media acquisition, defamatory campaign against business actors, journalists or business transaction to advertise in an independent outlet that would not be approved by the Prime Minister". ${ }^{77}$

Another layer of informal power can be identified through the advertisement market. Besides that the government clearly favored pro-government media with state advertisement and sideline non-governmental outlets, ${ }^{78}$ foreign investors stopped booking advertising in media independent of Fidesz. Conservative weekly newspaper Magyar Hang has been unable to sell advertising space to numerous multinational companies operating in Hungary. As one of my interviewees noted: the representative of the biggest German automotive company has openly admitted that although the readership of the newspaper is its "target audience", the company would not risk business privileges received from the Orbán government. ${ }^{79}$

Similarly, Index.hu tried to sell advertising space to large telecommunication and retail companies before 2020 but was rejected because they were concerned about their relationship with the government. ${ }^{80}$ It is unclear whether the behavior of these business actors is due to direct pressure or because of fear of economic or tax-related consequences. However, it is indicative of the informal power Orbán exerts on business actors by creating a huge chilling effect on the market. It is embedded into the broader context of external system-supportive factors. As Kelemen noted, ${ }^{81}$ the EU membership helped autocratic regimes access financing in a more indirect sense, by encouraging the inflow of Foreign Direct Investment (FDI). The Hungarian government also developed informal mechanisms that are less market-related on how to restrict media independent of the regime. ${ }^{82}$ Investigative journalists and Zoltán Varga, the owner of Central Media, the country's last remaining independent media, were under surveillance in 2019. Varga also claimed that he's been facing various

\footnotetext{
76 Interview with a former Hungarian journalist, 20 November, 2020.

77 Interview with Attila Bátorfy, assistant professor of journalism and media studies at the Media Department of Eötvös Loránd Science University, November 5, 2020, Budapest.

78 Bátorfy and Urbán (2019).

79 Research interview, November 16, 2020, Budapest.

80 Research interview, November 19, 2020, Budapest.

81 Kelemen (2020).

82 Inotai E (2021) “Orban government remain silent about Hungarian watergate”. 19, July, 2021.
} 
intimidation tactics from the Hungarian government and that two investors related to Fidesz were trying to buy Central Media. ${ }^{83}$

\section{2 "Repolonization" of the Media}

PiS attempted to follow Fidesz's footsteps in many ways to capture the media. Jaroslaw Kaczynski also perceives foreign ownership as a threat to national sovereignty. ${ }^{84} \mathrm{He}$ has been claiming for years that the majority of the press is under the influence of foreign (mainly German) actors, and he demanded the "re-polonization" of the media. In the World Press Freedom Index, Poland has fallen from its highest position of 18th in 2015 to its lowest position of 62 nd in $2020 .{ }^{85}$

Besides rewarding administrative positions, state-controlled companies are serving multiple strategic roles in Kaczynski's clientelist ecosystem. PiS has started to use powerful individuals aligned with the government to control media outlets independent of the executive branch. One new approach is that the government is incentivising state-owned companies to buy media wherever it is possible. ${ }^{86}$

Clientelist media ownership started to gain significant importance in his regime too. State-owned PKN Orlen purchased the Polska Press media organisation from its German owner media group Verlagsgruppe Passau. Daniel Obajtek, a close political ally of Kaczyński, now controls 20 out of Poland's 24 regional newspapers, more than 120 local magazines, 500 online portals with an outreach of 17 million users. It is also indicative that Kaczyński appointed Dorota Kania as the new, politically reliable editor-in-chief for these local papers. ${ }^{87}$

The government also uses state advertisements to fund friendly media and starve other outlets that are independent of the United Right. The public broadcaster (TVP) that became a party propaganda tool is immensely privileged by the state and the state-owned companies. During the last presidential election, the public television TVP waged a defamation campaign against the opposition's candidate, Warsaw Mayor Rafał Trzaskowski, portraying him as an incompetent candidate and the enemy of the Polish people, controlled by the "Jewish deep state." ${ }^{8}$ The platform is run by Jacek Kurski, one of Kaczyński's closest allies. Although there is no market or economic justification for such a dynamic growth of public funds for TVP, it received PLN 5.9 billion in state aid since $2016 .^{89}$

\footnotetext{
83 Harta V (2020) "24.hu-tulaj: a közelmúltban két befektető is megpróbálta "megvenni Orbánnak" a médiacégét." September 23, 2020. 24.hu.

84 Czuchnowski W, Kublik A (2020) “Kaczyński: Media in Poland should be Polish.” Gazeta Wyborcza, June 15. 2020.

85 Reporters without borders, 2020 World Press Freedom Index, 2020.

86 Notes from Poland (2021) "State-owned firms should buy media outlets "wherever possible", says Polish minister," October 13, 2021.

87 Czuchnowski W, Kublik A (2020) "Dorotę Kanię na szefową gazet Orlenu wybrał sam Kaczyński." Gazeta Wyborcza, May 7, 2020.

88 Gazeta Wyborcza, "US Senators express their concern over the rise of anti-Semitic discourse in Poland," September 18, 2020.

89 Mikolajewska B (2021) “TVP dostała 5,9 mld zł pomocy publicznej w 4 lata. Do tego setki milionów z państwowych spółek i instytucji.” 21, January 2021.
} 
With the help of state-owned companies, the government boosts the supportive private media outlets financially on the market. When it comes to televisions, 92.6 percent of advertising expenditure of state-owned companies was channeled towards two groups-TVP and Polsat. The public broadcaster was the main beneficiary, getting $53 \%$ of the overall funds. Despite that their market position is better, media platforms independent from the Polish government such as Gazeta Wyborcza and TVN remained unnoticed for the state advertisement.

Among the private media that openly support the Polish government, there has been fierce competition between the Karnowski brothers and Tomasz Sakiewicz. Both groups benefited greatly from their ties to PiS. Daily newspapers such as 'Sieci', 'Do Rzeczy', 'Gazeta Polska', Gazeta Polska Codziennie' and the weekly 'Wprost' are financed significantly by state-owned companies and ministries despite that their outreach is low. The structure of expenditures of state-owned companies shows a weak correlation between the level of advertising spending and the market position of the medium. The growing advertising revenues account for 3/4 of the profits of these groups that are financed by state companies like PKN Orlen, Lotto, and PGZ. As one of the experts put it: "These expenses constitute a large part of the advertising revenues of these titles and one gets the impression that some of them only exist thanks to the state. "90

While Gazeta Polska has been heavily subsidized by the state, Gazeta Polska "clubs" have also served as an important discussion platform for PiS. Since 1994, the platform has collaborated with PiS in the organization of demonstrations as well as in monthly commemorations of the 2010 Smoleńsk air crash in which President Lech Kaczyński died. ${ }^{91}$ The newspaper also disseminated "LGBT-free" stickers within one of its editions in 2019.

The media empire of the influential priest Tadeusz Rydzyk is another strategic platform for PiS, disseminating a "national-Catholic" ideology and backing the government's policies. ${ }^{92}$ Since 2015, Rydzyk has accumulated business companies, foundations, and a journalism school in Toruń. His popular Radio Maryja and Telewizja Trwam television channel have received PLN 214 million in state support from various governmental sources since PiS came to power including the Prime Minister's Office and ministerial departments. ${ }^{93}$

Between the pro-government and the government critical media, there is a group of platforms that would not openly spread PiS propaganda but avoid direct confrontation by tuning down criticism towards the government. Polsat television is the most important in this group. Its owner, Zigmund Solorz has various business interests not only in the media but also in the banking sector, the telecommunication and the energy sector as well. There was also a significant share of the Polsat

\footnotetext{
90 Interview with Tadeusz Kowalski, professor at the Media Department of the University of Warsaw, 30 April, 2021.

91 Interview with Marcin Ślarzyński, researcher at IFIS PAN, January 19, 2021, Warsaw.

92 Interview with Jan Kubik, professor of political science at Rutgers University in Budapest, November $19,2020$.

93 Mikolajewska B (2019) 214.158.441 złotych z publicznych pieniędzy na „dzieła” o. Rydzyka,” OKO Press, July 28, 2019.
} 
group $^{94}$ which together accounted for one-third of the spending $(33.2 \%)$ if the state owned companies. With the help of state-owned companies, the government boosts the supportive private media outlets financially on the market. When it comes to televisions, 92.6 percent of advertising expenditure of state-owned companies was channeled towards two groups-TVP (the public broadcaster) and Polsat. ${ }^{95}$

Other mechanisms of support come from banks not only in the form of advertising spendings but as significant loans too. Pro-government media groups are mostly being financed by banks linked to the sphere of influence of Morawiecki: PKO BP and Santander bank - the latter which was chaired and ruled by him before $2016 .{ }^{96}$

\section{Electoral Clientelism}

\subsection{Hungary: Coercive Vote-Buying}

The Orbán regime developed new informal methods to tilt the playing field during elections. According to the OSCE's Office for Democratic Institutions and Human Rights (ODIHR), low-intensity political coercion was employed by the authorities in Hungary in the last parliamentary elections in $2018 .{ }^{97}$ For example, the State Audit Office discriminated against opposition parties by levying fines against them, while Fidesz was not fined during the campaign.

One of these tools is the increased pressure on opposition ballot-counting officers, who are part of the committees in electoral districts that conduct voting to make sure that the elections are lawfully implemented. Our expert interviews pointed out that they are often intimidated and stigmatized by the representatives of the government. ${ }^{98}$ Ballot counters that were not delegated by Fidesz are often not allowed to actively take part in the committee's responsibilities; for instance, handling the electoral rolls or accompanying mobile ballot boxes to pensioners' homes. ${ }^{99}$

While Fidesz considers the workfare program for recipients of public support to be an important aspect of Roma integration, it also uses this as an effective tool of coercion during elections. ${ }^{100}$ Intimidation and threats to withdraw social benefits were common practice in the last elections, impacting the most vulnerable citizens and particularly the Roma. Empirical research ${ }^{101}$ shows that it could secure 5-6 mandates for the ruling without which Orban could not get a constitutional majority.

\footnotetext{
94 Polsat, Polsat News, Superpolsat, TV4, TV6, Fokus TV, Eska TV, Polo TV.

95 Kowalski T (2021) "Report. Advertising expenditures of state-owned companies. Poland 2015-2020".

96 Interview with Tomasz Piatek, investigative journalist, July 4 2021, Warsaw.

97 OSCE Office for Democratic Institutions and Human Rights, Report on the Hungarian Parliamentary elections, 2020.

98 Interview with Zsófia Banuta from Unhack Democracy, October 20, 2020, Budapest.

99 Melani Barlai and Zsófia Banuta, Unhack Democracy Europe Key Findings, April 8, 2018.

100 Mares I, Young L (2019) Varieties of clientelism in hungarian elections comparative politics 51(3): 449-480 (32).

101 Mizsur A (2021) Megmérték: minél több a közmunkás a faluban, annál többen szavaznak a Fideszre." October 19, 2021.
} 
Actors such as money lenders also play a significant role in this. Not only can they put pressure on deprived citizens to support Fidesz, in exchange for small sums from the party, they often actively participate in the organized transportation of Roma voters who are to vote for it, although they often "do not even know what they are doing on the spot." 102

According to one of my interviewees, Józsefváros became a "laboratory" of Budapest in this regard, where Fidesz involved a local, influential gipsy entrepreneur in terms of vote buying in the 2019 municipal elections. This person monopolized the local construction market until 2019 and provided job opportunities only for those who were willing to vote for the nominee of Fidesz, Sára Botond in the elections. This informal network facilitating coercive vote-buying procedure is usually extended by members of the citizens Police who are employing intimidation tactics among the most deprived local citizens. ${ }^{103}$ Given that intimidated people are afraid to share such information, it is much more difficult for international observers to identify than direct election fraud.

\subsection{Poland: Instrumentalizing COVID to Tilt the Playing Field}

According to the OSCE's electoral mission, elections in Poland met the most important democratic criteria up to the parliamentary elections in 2019. Besides individual cases, there were no systemic irregularities that would put in doubt the reliability of the 2019 results. ${ }^{104}$ As one of my interviewees noted, it was the 2020 presidential election that marked a "dramatic change". ${ }^{105}$ Held after the outbreak of the coronavirus pandemic, there have been serious doubts raised about the fairness of the contest.

Despite that the ODIHR once again declared that the authorities handled the 2020 election professionally, it also found that various political and legislative decisions violated procedural norms and the principles of the electoral law. ${ }^{106}$ Instead of introducing a state of emergency and postponing the election due to the pandemic, the government decided to hold the poll at all costs, disregarding the risks posed by the coronavirus.

Firstly, the government postponed the election by several weeks as part of a backroom deal between Kaczyński and a rebel coalition partner, Jaroslaw Gowin. This decision by two party leaders without any constitutional responsibility once again showed that the real center of power is elsewhere than it is defined by the Polish constitution. Furthermore, the constitution states that the electoral law cannot be amended less than six months before elections are announced, and thus Kaczyński

\footnotetext{
102 Interview with Melani Barlai, assistant professor at Andrassy University, December 4, 2020, Budapest.

103 Research interview in Budapest, April 21. 2021.

104 OSCE Office for Democratic Institutions and Human Rights, Final report on the parliamentary elections in Poland, 2019.

105 Interview with Adam Bodnar, ombudsperson of Poland, November 10, 2020, Budapest.

106 OSCE Office for Democratic Institutions and Human Rights, Final report on the presidential elections in Poland, 2020.
} 
used the pretext of COVID to unconstitutionally secure power for PiS in the long run.

One of the greatest concerns was the decision to change the electoral law in order to hold the election by mail voting only. The Warsaw's Provincial Administrative Court also found that Prime Minister Morawiecki had committed a "gross violation of the law" and the constitution when ordering preparations for the vote to be held while the postal vote issue was still being debated in the parliament. ${ }^{107}$

Rafał Trzaskowski, the opposition's candidate, did not have equal opportunities in the race with Andzrej Duda. While the President took advantage of state resources with his presidential trips during the campaign, his opponent's moves were significantly limited by the coronavirus lockdown. The state and PiS's nominee were inseparable, with high-ranking officials conducting campaign activities and mobilizing state resources to support President Duda. For example, free fire trucks were promised to settlements with less than 20,000 inhabitants. A profound example of the misuse of state resources was when the Agriculture Social Insurance Fund disseminated to 1.3 million households a letter from the president in which he expressed his support for Polish farmers. ${ }^{108}$

In addition, Duda's social media campaign was in question. One of their main contractors, HyperCrew was funded by a company (Czysta3.vc) that had previously received state support from a public institution responsible for research and development. ${ }^{109}$ The Polish Catholic Church also mobilized significant resources on behalf of Duda. Its support for PiS mostly occurs in small parishes where often party posters and leaflets are displayed in churches. As another interviewee noted, the lack of separation between the state and the church in this regard is most evident in smaller municipalities. $^{110}$

\section{Conclusions}

The purpose of this article is to argue that democratic backsliding in Central Eastern Europe is driven not only by the violation of the rule of law but by undermining democracy with informal exercise of power. Similarly to the argument made by Jasiecki, ${ }^{111}$ this article claims that both regimes have established an autocratic state governance in which business and political alliances are taking advantage of companies for the benefit of the ruling elite. These actors are rent seeking which leads to the "hybridization of fuzzy ownership structures and unclear interdependencies

\footnotetext{
107 Notes from Poland, "Polish prime minister committed "gross violation of law" in organising elections, rules court," September 15, 2020.

108 Flis D (2020) Duda robi kampanię za publiczne pieniądze. KRUS rozesłał jego list do nawet 1,3 mln osób," OKO.press, April 16, 2020.

109 Kacprzak I (2020) Kampania Andrzeja Dudy, NCBiR i miliony złotych. July 16, 2020.

110 Interview with Marek Tatala, vice president and economist at the Civil Development Forum, October 22, 2020, Budapest.

111 Jasiecki (2019).
} 
between state owned subsidies". ${ }^{112}$ Besides the legal power vested in the offices they have, both leaders created additional sources through which they could cement political power: they set up their own political system configuration of associates to serve their political purposes. It had a profound negative impact on the quality of institutions while shifting various forms of state capture and clientelist corruption to a new gear in both countries.

The Orbán and Kaczynski regimes also wield power informally through media capture and by using powerful individuals and companies to silence or turn over media outlets independent of the government. Both regimes have also learned to develop new ways to tilt the playing field in an informal way that is more difficult for international electoral observers to identify than outright fraud.Although the opposition could compete for the executive power in a meaningful way, due to the above mentioned features of the election, the competition is grossly unfair.

Another feature of these systems is the lack of investigation of high-level cases of corruption and nepotism. It stems not only from the partisanship of the Public Prosecutor's Offices. The secret services and law-enforcement authorities also remain passive in both countries. ${ }^{113}$ Similarly, the politically captured competition and media authorities, and constitutional courts/tribunals provided a comfortable way to incentivise media acquisitions beneficial for the ruling camps and to block media mergers that were unfavored by the ruling camps.

While previous Hungarian and Polish governments have also developed their clientelistic network and had corruption-related problems, the Orbán and Kaczynski regimes have changed this dynamic in various key aspects. The most important difference is that Fidesz and the United Right weakened the rule of law and undermined all institutional checks and balances that have made the state vulnerable to systemic corruption and political clientelism. Fidesz has also achieved a monopolistic position regarding the distribution of resources and sidelined all rival clientelist networks.

While the constitutional majority in Parliament provided Viktor Orbán greater legitimacy to act, the robustness gap between Hungary and Poland is not confined to input legitimacy differences when it comes to informal exercise of power. There are three main factors that make the nature of corrupt clientelism under PiS and Kaczynski in Poland is markedly different from that under Fidesz and Orbán in Hungary.

First, partly due to the Polish institutional design of decentralization and multilevel governance, it is a lot more difficult to politicize the state in terms of a political and economic monopoly. While the Orbán regime used a wide range of allies to capture the most important economic sectors by 2021, this centralized political state capture is not yet prominent in the Polish context. Whereas these clients are heavily dependent on Viktor Orbán without meaningful autonomy, the clients of the Polish government are connected to Jaroslaw Kaczynski throughout various power flanks in the United Right. It also gets very difficult for him to maintain control over the competing groups in a decentralised, multilevel governance system.

\footnotetext{
112 Jasiecki (2019).

113 Interview with Grzegorz Makowski.
} 
Secondly, the key difference lies in the level of autonomy of the clients. Similarly to the argument of Magyar and Madlovics, ${ }^{114}$ this article claims that the Orbán regime created a grossly asymmetric patron-client regime in which the clients are lacking autonomy. Also, while the level of coercion is increasing, it is still more limited in Poland where PiS inserts pressure mostly on political and judicial stakeholders, MPs and media outlets independent of the government.

Thirdly, this article argues that non-democratic informality serves a twofold role in the Orbán regime: to accelerate both economic and political gains. The main drives of informality are not external economic actors, but the Hungarian Prime Minister himself. In contrast to that, while Jaroslaw Kaczynski qualifies as Poland's informal leader, the main venue of political clientelism is still PiS where partisanship and personal loyalty towards him both matter. Actors such as the Polish Catholic church and Tadeusz Rydzik have some influence on decision-making.

These findings also carry important policy implications for the EU. The Orbán and the Kaczynski regimes have both benefited from the modus operandi of integration. While they often operate outside the legal framework, the EU operates in a deeply legalized environment where long-lasting procedures are rather avoiding sanctions against member states.

Informal exercise of power has a profound negative impact on democracy by further undermining trust in democratic institutions, reducing accountability, distorting the representation circle and leading to unfair provisions of public services. The warning for the EU is that Orbán and Kaczynski will not stop proceeding by these informal means. Therefore, undermining democracy with various informal tools will not disappear any time soon from within Europe.

Publisher's Note Springer Nature remains neutral with regard to jurisdictional claims in published maps and institutional affiliations.

$\overline{114}$ Magyar B, Madlovics B (2020) The anatomy of post-communist regimes: a conceptual framework. CEU Press. 